\title{
A Go-precipitation Method for the Preparation of Transforming DNA from Small Samples of Low Density Bacterial Cultures
}

\author{
BY L. O. BUTLER \\ Laboratoire de Génétique Physiologique du C.N.R.S., Gif-sur-Yvette, France and \\ *Department of Bacteriology, St George's Hospital Medical School, London, S.W. 1
}

(Received 16 November 1964)

\begin{abstract}
SUMMARY
A method is described for the preparation of transforming DNA from $1 \mathrm{ml}$. samples of pneumococcal cultures of low density (e.g. about $10^{7}$ bacteria). It seemed likely that the precipitation of very small amounts of transforming DNA from lysates of dilute pneumococcus cultures might result in loss of DNA unless a suitable co-precipitant was added. With high dilutions of transforming DNA, it was confirmed that such a loss was obtained. This loss was largely prevented by the addition of sodium hyaluronate in the presence of citrate. Dextran was not as efficient as hyaluronate as a co-precipitant.
\end{abstract}

\section{INTRODUCTION}

The study of certain reactions in bacterial transformation involves the use of lysates of relatively small numbers of bacteria as the source of the transforming DNA. It may sometimes be sufficient for a sample of the culture to be lysed with deoxycholate and used without further purification (e.g. Voll \& Goodgall, 1961), but in some cases it may be desirable to remove substances present in the culture fluid before the lysates are assayed for transforming activity. When the lysates are prepared from $1 \mathrm{ml}$. samples of suspension containing perhaps not more than $10^{7}$ bacteria, simple centrifugation before lysis might involve the risk of loss of some organisms. Hence, a precipitation method is indicated. Fox \& Hotchkiss (1960) lysed the bacteria with deoxycholate followed by precipitation with $1 \cdot 3$ vol. of ethanol, centrifugation, and re-solution of the pellet. However, with such small numbers of bacteria the precipitation and recovery of DNA might be incomplete unless a carrier be added. Dr Harriet Ephrussi-Taylor (personal communication) has found that type-specific pneumococcal polysaccharide can act as a suitable coprecipitant with pneumococcal DNA, but its unavailability makes it unsuitable for general use. It was, therefore, decided to test sodium hyaluronate as a co-precipitant, and the results obtained are reported here.

\section{METHODS}

Organisms. Streptococcus pneumoniae $\mathrm{Cl3}$, the receptor organism sensitive to streptomycin; $S$. pneumoniae $\mathrm{r}_{2} \mathrm{SQ}$, derived from $\mathrm{Cl} 3$ but resistant to streptomycin, optochin and erythromycin at the ery- $\mathrm{r}_{2}$ level (Ravin \& Iyer, 1961). Both strains

* Present address. 
were maintained in medium as described by Martin \& Ephrussi-Taylor (1964), with the addition of defibrinated rabbit blood to $2 \%(\mathrm{v} / \mathrm{v})$.

$D N A$. Prepared from a lysate of a culture of Streptococcus pneumoniae strain $\mathrm{r}_{2} \mathrm{SQ}$ made by incubating with $0.6 \%(\mathrm{w} / \mathrm{v})$ sodium deoxycholate at $37^{\circ}$ for $30 \mathrm{~min}$, Crude DNA was precipitated by 2 vol. ethanol in the presence of citrate, most of the fibrous precipitate obtained being collected by winding on to a glass rod and the rest by centrifuging after decanting most of the mother liquor. A citrate+ saline solution of the precipitate was deproteinized by repeated shaking with $\mathbf{0 . 3 3}$ vol. chloroform and $0 \cdot 1$ vol. capryl alcohol followed by final precipitation with 2 vol. ethanol. The DNA threads were wound immediately on to a glass rod and dissolved in sterile $0 \cdot 15 \mathrm{M}-\mathrm{NaCl}$. The concentration of the DNA solution was not determined, but from the experience obtained with previous preparations it was estimated that it was of the order 50-100 $\mu \mathrm{g}$. DNA $/ \mathrm{ml}$.

Sodium hyaluronate solution. Sodium hyaluronate (Grade 1, Sigma Chemical Co., St Louis, Mo., U.S.A.) was dissolved in $0.15 \mathrm{M}-\mathrm{NaCl}$ to concentrations of 0.5 and $2.0 \mathrm{mg} . / \mathrm{ml}$.

Dextran solution. Dextran powder (Glaxo Laboratories Ltd., Greenford, Middlesex, England; Clinical/Technical Grade), having $46 \%$ of molecular weight between 51,000 and 150,000 , was dissolved in $0 \cdot 15 \mathrm{Mr}-\mathrm{NaCl}$ to $20 \mathrm{mg} . / \mathrm{ml}$.

Assay of transforming activity. A 'preculture' of competent receptor bacteria was obtained by inoculating $\mathbf{0 . 2 5} \mathrm{ml}$. of the stock Streptococcus pneumoniae strain $\mathrm{Cl} 3$ into $5 \mathrm{ml}$. ' $\mathrm{P}$ ' medium ( $1 \%(\mathrm{w} / \mathrm{v})$ Difco Neopeptone, $0 \cdot 8 \%(\mathrm{w} / \mathrm{v})$ charcoal-absorbed Difco yeast extract, $0.025 \%(\mathrm{w} / \mathrm{v})$ glucose, $\mathrm{pH} 7 \cdot 6)$, and incubating at $37^{\circ}$ for $2 \frac{1}{4} \mathrm{hr}$. From this a competent culture was obtained by inoculating $\mathbf{0 . 4} \mathrm{ml}$. preculture into $10 \mathrm{ml}$. 'NS' medium ( $1 \%(\mathrm{w} / \mathrm{v})$ charcoal-absorbed Difco Neopeptone, $0.8 \%(\mathrm{w} / \mathrm{v})$ charcoal-absorbed Difco yeast extract, $0.025 \%(\mathrm{w} / \mathrm{v})$ glucose, containing $\mathrm{CaCl}_{2}$ and a fresh extract of yeast as required), plus $0 \cdot 1-0 \cdot 2 \%(\mathrm{w} / \mathrm{v})$ crystalline bovine albumin, and incubating at $37^{\circ}$ until competence appeared. In some cases the preculture was frozen at $-70^{\circ}$ (in the presence of $10 \%, \mathrm{v} / \mathrm{v}$, glycerol) and stored at this temperature in $0.5 \mathrm{ml}$. lots. When required, a $0.5 \mathrm{ml}$. sample was rapidly thawed and used for the preparation of the competence culture. Fifteen minutes before competence was expected, the culture was cooled in ice and $1 \mathrm{ml}$. samples added to $5 \mu \mathrm{l}$. or $10 \mu \mathrm{l}$. samples of DNA solution and the mixture incubated at $37^{\circ}$ for $30 \mathrm{~min}$. Suitable dilutions were plated in triplicate in a nutrient agar medium containing blood and incubated for $2 \mathrm{hr}$ to allow expression of the gene conferring streptomycin resistance. At the end of this time, the plates were overlayered with nutrient agar containing streptomycin to give a final concentration in the plate of $200 \mu \mathrm{g}$. streptomycin/ml. The colonies grown on the plates after a further 24-48 hr incubation at $37^{\circ}$ were counted, and the average of the triplicate platings calculated. Since there is no mutation to streptomycin resistance at this level, no control plates were necessary.

\section{RESULTS}

Effect of added hyaluronate on transforming activity. Amounts of sodium hyaluronate were mixed with suitable dilutions of the DNA solution to give the ratios indicated in Table 1. The mixture was then assayed for its transforming activity, which was compared with the activity of the DNA solution without added hyal- 
uronate. No immediate effect on the transforming activity was noted, but a marked decrease occurred after the mixture with hyaluronate had been allowed to stand at $4^{\circ}$ for $24 \mathrm{hr}$. Heating the hyaluronate in a boiling water-bath for $8 \mathrm{~min}$. did not prevent the deterioration except with the lowest concentration of hyaluronate. However, the addition of $0 \cdot 3 \mathrm{M}$-trisodium citrate to final concentration $0 \cdot 15 \mathrm{M}$ trisodium citrate limited the decrease to $20-25 \%$ after $24 \mathrm{hr}$.

Table 1. Effect of the presence of hyaluronate on the transforming activity of DNA

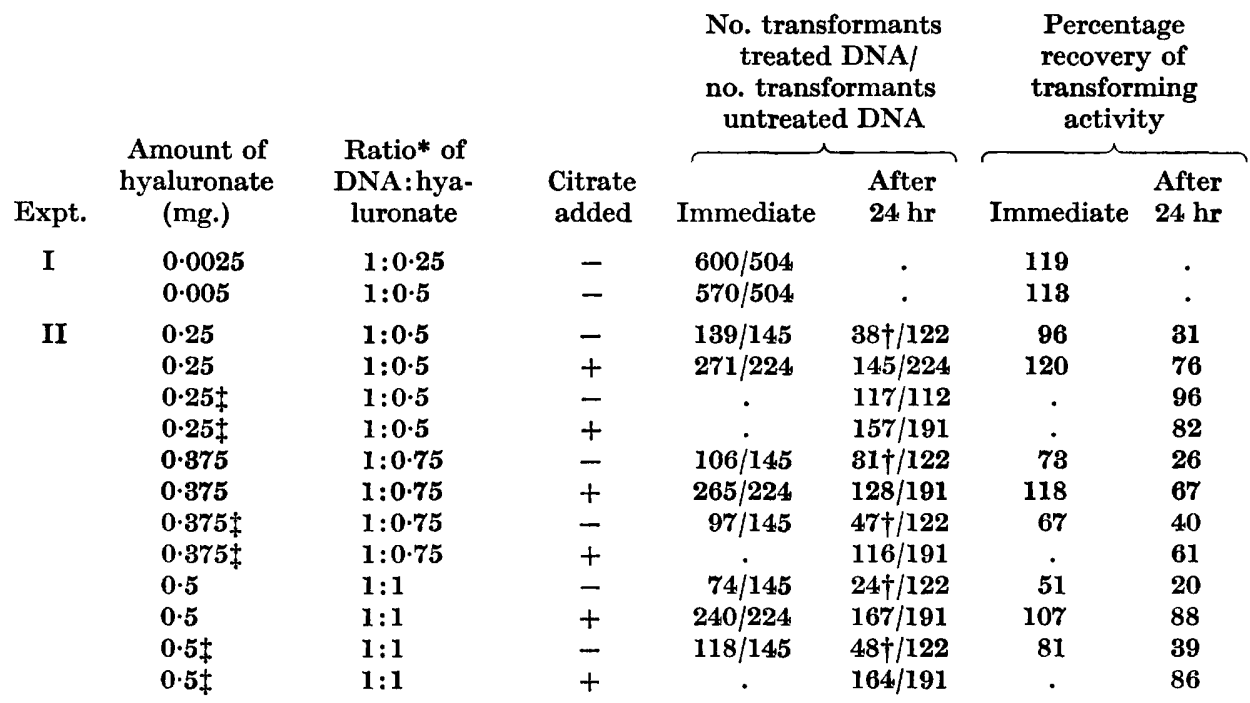

* The DNA concentration was not known exactly but the same solution was used for all experiments and was estimated to contain $1-2 \mu \mathrm{g}$. DNA/ml. The ratio is expressed as 1 vol. DNA : mg. hyaluronate, where 1 vol. was estimated to be equivalent to 1-2 $\mu \mathrm{g}$. DNA. A change in the value of one side of the ratio shows that the concentration of the substance represented by that side of the ratio was changed while the concentration of the substance of the other side remained constant.

$\dagger$ Average number of transformants of six plates done at two dilutions.

+ Hyaluronate solution heated for $8 \mathrm{~min}$. in boiling water-bath and cooled before mixing with DNA.

Co-precipitation of DNA. A suitable dilution of DNA in $1 \mathrm{ml}$. samples was mixed with various amounts of hyaluronate with or without sodium citrate to $0 \cdot 15 \mathrm{M}$ citrate in conical centrifuge tubes. The mixtures were cooled in ice, 2 vol. ethanol added and shaken to ensure good mixing. The tubes were then allowed to stand in ice for $1 \mathrm{hr}$. to allow flocculation of precipitate, and centrifuged. The supernatant fluids were decanted, and the tubes allowed to stand inverted on an absorbent tissue for $1 \mathrm{hr}$. When possible excess liquid was wiped from the inside of the tubes with absorbent tissue, and $1 \mathrm{ml} .0 \cdot 15 \mathrm{M}-\mathrm{NaCl}$ or $1 \mathrm{ml}$. of a mixture of 1 vol. $0 \cdot 15 \mathrm{M}$ $\mathrm{NaCl}+1$ vol. $\mathbf{0} \cdot 3 \mathrm{M}$-citrate added. The precipitates were loosened from the walls of the tube by shaking, and left to dissolve at $4^{\circ}$ for 24 and $48 \mathrm{hr}$. The DNA solutions were then assayed for their transforming activity and compared with a sample of the original dilution of DNA which had not been processed. The results obtained are shown in Table 2. It can be seen that without citrate there was a diminution of the transforming activity, whereas with citrate the recovery of even minute amounts of 


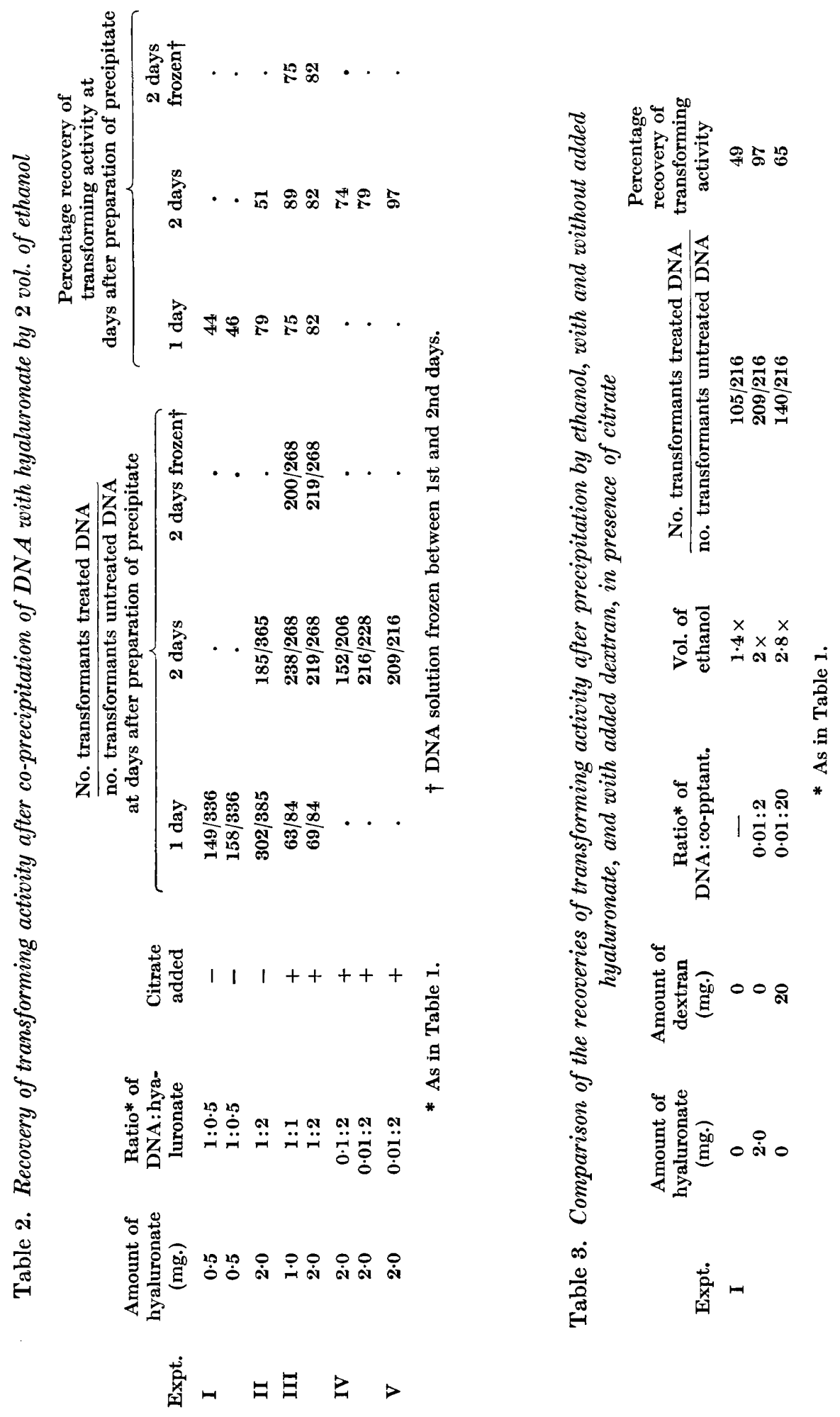


DNA was about $85 \%$ of the original activity. This figure compares well with that obtained in the presence of hyaluronate but without the precipitation of the DNA. Therefore, no loss was obtained as a result of the precipitation. It can also be seen that there was no advantage obtained by keeping the dissolved precipitates frozen between the first and second day.

Comparison was made of the recovery of transforming activity after precipitation with $(a)$ hyaluronate, $(b)$ dextran as co-precipitant, $(c)$ no co-precipitant. In all three cases citrate was added. The systems $(b)$ and $(c)$ had to be modified. The dextran had to be about ten times more concentrated than hyaluronate before a good precipitate was obtained, and more ethanol was required. Also, after centrifuging, a further period of cooling in ice was desirable before decantation, since the refractive index of the precipitate appeared to change and the precipitate could not be seen unless kept at $0^{\circ}$. It was also found that in the case of systems $(b)$ and $(c)$ and with this concentration of citrate, a small amount of an immiscible liquid was formed when the ethanol was added. The volume of ethanol added was critical. In absence of co-precipitant, the amount of ethanol had to be decreased to $1 \cdot 4 \mathrm{vol}$., and with dextran, the maximum permissible was $\mathbf{2 \cdot 8} \mathrm{vol}$. The results are given in Table 3 . It can be seen that in the absence of co-precipitant there was only $50 \%$ recovery of activity; with the dextran system there was better recovery but much less than with hyaluronate.

Application to lysates. It was required to prepare DNA for the assay of transforming activity from samples of not more than $1 \mathrm{ml}$. of bacterial cultures of pneumococci having about $10^{7}$ organisms $/ \mathrm{ml}$. On the basis of the above findings, the procedure adopted was as follows. To $1 \mathrm{ml}$. of the coccal suspension in a conical centrifuge tube was added $1.0 \mathrm{ml} .0 \cdot 3 \mathrm{M}$-sodium citrate and $0.1 \mathrm{ml} .5 \%(\mathrm{w} / \mathrm{v})$ sodium deoxycholate. The cocci were allowed to lyse for $30-40 \mathrm{~min}$. at $37^{\circ}$. To the lysates were added $2.0 \mathrm{ml}$. sodium hyaluronate solution (containing $2.0 \mathrm{mg}$. sodium hyaluronate $/ \mathrm{ml}$.), followed by $8.0 \mathrm{ml}$. (i.e. 2 vol.) ethanol. After mixing, the tubes were allowed to stand in ice for $1 \mathrm{hr}$, centrifuged and the supernatant liquid decanted. The tubes were stood inverted at room temperature for $1 \mathrm{hr}$ and excess fluid removed by careful wiping with absorbent tissue. The precipitate was dissolved in $1 \mathrm{ml}$. of a solution containing equal volumes of $0 \cdot 15 \mathrm{M}-\mathrm{NaCl}$ and $0.3 \mathrm{M}$ citrate. To allow complete solution, the activity of the DNA was not usually assayed before $40 \mathrm{hr}$.

\section{DISCUSSION}

The results recorded in Table 3 confirmed that precipitation of very small amounts of DNA without a co-precipitant might lead to a substantial loss. In the case of a bacterial lysate the bacterial protein may act as a co-precipitant, but its efficiency would probably depend on the number of organisms present and thus vary. It is obviously desirable to provide a co-precipitant at a known concentration; sodium hyaluronate is adequate for this purpose. The deterioration of the transforming activity observed in the earlier experiments was presumably due to contamination of the hyaluronate used with DNase, since it was stopped by adding citrate. In some experiments (not reported here) with a crude preparation of RNA as co-precipitant, low activities were also obtained although the volume of precipitate was satisfactory. This system was not investigated further, but it seems 
likely that the RNA used was also contaminated with DNase. Different samples of hyaluronate may contain different amounts of DNase, but the use of citrate will protect the DNA from this enzyme. It is, of course, necessary to have a DNase inhibitor present when the bacteria are lysed, to protect the DNA from the endogenous DNase.

Although it was not tested, there is no reason to suppose that this procedure would not be suitable for fewer bacteria but with very large numbers it may not be necessary to add the co-precipitant.

Thanks are due to Dr H. Ephrussi-Taylor for helpful discussions and for hospitality. Acknowledgement is also given to the French Government and Medical Research Council for the award of a French Government Exchange Fellowship, and to the Endowment Fund of St George's Hospital for the award of a grant.

\section{REFERENCES}

Fox, M. S. \& Нотснкіss, R. D. (1960). Fate of transforming deoxyribonucleate following fixation by transformable bacteria. I. Nature, Lond. 187, 1002.

Martin, C. \& Ephrussi-Taylor, H. (1964). Effects of partial deuteration in transforming DNA of pneumococcus. Biochim. biophys. Acta, 80, 411.

RAvin, A. W. \& IYER, V. N. (1961). The genetic relationship and phenotypic expression of mutations endowing pneumococcus with resistance to erythromycin. J. gen. Microbiol. 66, 1.

Voll, M. J. \& Goodgall, S. H. (1961). Recombination during transformation in Haemophilus influenzae. Proc. natn. Acad. Sc. U.S.A. 47, 505. 